\title{
Impact of Natural Rubber Tire Waste Charcoal on Selected Soil Physical Characteristics of Tea Growing Soils
}

\section{A.P.I Mendis ${ }^{1}$, B.C.Walpola ${ }^{2 *}$ and HKMS Kumarasinghe ${ }^{1}$}

${ }^{1}$ Department of Crop Science,

Faculty of Agriculture, University

of Ruhuna, Sri Lanka

${ }^{2}$ Department of Soil Science,

Faculty of Agriculture, University

of Ruhuna, Sri Lanka

Correspondence:

*bcwalpola@soil.ruh.ac.lk

(D) https://orcid.org/0000-0002-4663-0943

DOI: http://doi.org/10.4038/sljae.v3i2.71

\begin{abstract}
The present study assessed the impact of application of natural rubber tire waste charcoal (NRTWC) on selected physical characteristics of tea cultivated soils which belongs to Red Yellow Podzolic great soil group. Natural rubber tire waste charcoal was applied as a soil amendment at different rates $(0 \%, 1 \%, 1.6 \%, 2.2 \%$ and $2.8 \%$ w/w). Physical attributes of soil; bulk density, particle density, porosity, texture and aggregate stability were assessed at 10 and 20 weeks after application of NRTWC. Natural rubber tire waste charcoal significantly improved physical characteristics of soil by reducing soil bulk density, and increasing particle density, porosity and aggregate stability. Natural rubber tire waste charcoal treated soils showed significantly $(p \leq 0.05)$ lower bulk densities for the application rates of $2.2 \%$ and $2.8 \%$ (1.21 and $1.17 \mathrm{gcm}^{-3}$ respectively) compared to the control $\left(1.39 \mathrm{gcm}^{-3}\right)$ at 10 weeks after application. Significantly $(p \leq 0.05)$ lower particle density was observed for the application rate of $2.8 \%\left(2.52 \mathrm{gcm}^{-3}\right)$ than the control at 20 weeks after application. The increased porosity with time might be attributed to the increased of soil organic matter content with the application of NRTWC. The highest porosity change was observed at $1 \%$ treatment (from $44.9 \%$ to $48.8 \%$ ) and the lowest was at $2.8 \%$ (from $49.4 \%$ to $56.3 \%$ ). Despite no significant ( $p \geq 0.05$ ) difference was reported in particle size distribution in soil treated with NRTWC, there was a noticeable decreased in sand percentage and increased in either silt or clay percentages at 20 weeks after application. Soil aggregate stability was found to be significantly increased $(p \leq 0.05)$ in all treatments at 10 and 20 weeks after NRTWC application compared to the control. However, further investigations are needed before recommending the addition of NRTWC as an amendment to tea growing soils.
\end{abstract}

Keywords: Bulk density, Organic carbon, Porosity, Red yellow podzolic soil, Soil amendments 


\section{Introduction}

An enormous amount of tire wastes has been discarded throughout the world every year causing negative impacts on the environment (Thomas et al. 2016; Czajczynska et al. 2017). A substantial fraction of these tires is used in landfilling or discarded as garbage without proper treatment. The number of waste tires is estimated to be increased to five billion by the year 2030, (Thomas et al. 2016) leading a significant disposal and storage problems in landfill and stockpiles (Dhir et al. 2001). Pyrolysis, incineration, retreading, gasification and landfill are found to be the common method of tire disposal (Undri et al. 2013; Duan et al. 2015; Li et al. 2016). Due to their nonbiodegradable nature, and discarded rubber tires may cause "black pollution" (Nehdi and Khan 2001). Landfilling on the other hand is also not recommended due to possible floating on the top over time (Juma et al. 2006). Therefore, it is of prime importance to discover safe and useful method to discard waste tires without harming the environment. Pyrolysis oil, pyrolysis gas and solid coke etc. are outcomes of pyrolysis, thus it is considered as an economically viable and environmentally friendly method (Williams 2013).

The solid coke is composed of industrial carbon black (CB), ash, inorganic filler, etc., which can be further recycled (Wang et al. 2014; Zhang et al. 2018). According to Junqing et al. (2020), pyrolytic CB is very much similar in nature to the biochar. Therefore, uses of carbonaceous materials produced through the thermal decomposition are capable of increasing soil organic carbon content. Pyrolytic CB is recalcitrant to decomposition and maintains soil organic carbon levels for a longer period of time.

Tea is a perennial crop with a commercial life span of about nearly 30-50 years (Gunathilaka 2018). Sri Lankan tea industry is considered as one of the largest agriculture based industries in Sri Lanka and it contributes $2 \%$ to the Gross Domestic Production (Cental Bank Report 2020). Out of the total land area used for agriculture, $28 \%$ is used for tea cultivation (Mapa et al. 2002). However, most of the tea growing soils in Sri Lanka are being subjected to severe degradation and continuously declining in soil organic matter leading to poor soil fertility (Jayasinghe et al. 2019. Degradation 
process is further accelerated by unfavorable environmental conditions, soil erosion of steeply sloping lands and heavy use of agrochemicals which cause faster decomposition of soil organic matter (Lal et al. 2015). According to Jayasinghe et al. (2019), the most suitable lands for tea cultivation in Sri Lanka are located in Nuwara Eliya, Ratnapura, Matara, Galle, Matale, Kandy, Badulla, Kegalle and Kalutara districts where red yellow Podzolic soil type is predominant.

In recent decades, application of organic amendments to reverse soil degradation has gained worldwide attention. It is considered as cost-effective and environmental friendly approach which helps to achieve sustainable production through improving chemical, physical and biological properties of the soil. Improvement of soil organic matter level through the tire waste charcoal is known to influence physical features of the soil (Al-Neami 2018). The effects of charcoal on soil bulk density, particle density, porosity and texture have not been fully evaluated in tea cultivated lands under field conditions. Therefore, this study aimed at investigating major soil physical characteristics of red yellow podzolic soils amended with natural rubber tire waste charcoal (NRTWC).

\section{Materials and Methods}

\section{Experimental Site}

Well-managed eight years old tea plantation located at Aturaliya Divisional Secretariat of Matara district in Southern Sri Lanka was selected for the study. The selected area comes under the agroecological region low country wet zone (WL2). The soil used in this study belongs to Ultisols, which is known as Red Yellow Podzolic (local classification) and is classified as Hapludults according to the USDA soil taxonomy (Mapa et al. 1999). Table 1 shows some selected physical and chemical characteristics of the soil. The $\mathrm{pH}(1: 2.5)$ and the electrical conductivity (EC) (1:5) were measured using a $\mathrm{pH} / \mathrm{EC}$ meter (HANNA-PI 98130). The $\mathrm{NH}_{4}{ }^{+}-\mathrm{N}$ content was determined utilizing the Berthelot reaction (Searle, 1984) and the $\mathrm{NO}_{3}{ }^{-}-\mathrm{N}$ by sodium salicylate yellow colour method (Bremner, 1960). Available phosphorous extracted by the bicarbonate method was determined following the molybdate blue color method (Murphy, Riley 1962). Exchangeable $\mathrm{K}, \mathrm{Na}$ and $\mathrm{Ca}$ were 
determined using a flame photometer (Blackmore et al., 1987) and the wet oxidation method (Tiessen and Moir, 1993) was applied to determine soil organic matter content.

Table 1: Some important physico-chemical properties of soil in the experiment site.

\begin{tabular}{|c|c|}
\hline Soil Properties & Values* \\
\hline Organic matter (\%) & $2.25 \pm 0.008$ \\
\hline Organic carbon (\%) & $1.29 \pm 0.008$ \\
\hline Bulk Density $\left(\mathrm{g} \mathrm{cm}^{-3}\right)$ & $1.39 \pm 0.06$ \\
\hline Particle Density $\left(\mathrm{g} \mathrm{cm}^{-3}\right)$ & $2.49 \pm 0.07$ \\
\hline Porosity (\%) & $44.83 \pm 1.1$ \\
\hline $\mathrm{pH}$ & $5.3 \pm 0.4$ \\
\hline $\mathrm{EC}\left(\mathrm{dS} \mathrm{m} \mathrm{m}^{-1}\right)$ & $0.035 \pm 0.005$ \\
\hline $\mathrm{NO}_{3}^{-}-\mathrm{N}\left(\mathrm{mg} \mathrm{kg}^{-1}\right)$ & $1.78 \pm 0.09$ \\
\hline $\mathrm{NH}_{4}{ }^{+}-\mathrm{N}(\mathrm{mg} \mathrm{kg}-1)$ & $11.69 \pm 0.14$ \\
\hline Available P (mg kg-1) & $2.15 \pm 0.42$ \\
\hline Exchangeable Ca (mg kg-1) & $146.52 \pm 6.79$ \\
\hline Exchangeable K (mg kg-1) & $14.21 \pm 0.55$ \\
\hline Exchangeable $\mathrm{Na}$ (mg kg-1) & $9 \pm 0.45$ \\
\hline
\end{tabular}

\section{Production of Natural Rubber Tire}

Waste Charcoal (NRTWC)

Waste tires (DSI) were collected from dumping sites of tire shops from Akuressa and Kaburupitiya areas of Matara district, Sri Lanka. Excavated pit (one cubic meter) was tightly filled with waste tires and covered with excavated soil and thick metal sheet to seal up the chamber. Oxygen supply was regulated to control burning process. Pyrolysis was stopped by excluding oxygen followed by pouring the water. This method is considered to be one of the oldest and simplest methods of charcoal making which is still widespread. The NRTWCs were then air dried, broken up to pieces with a hammer and crushed charcoals were passed through $250-\mu \mathrm{m}$ mesh to remove larger particles. Physical and chemical characteristics of NRTWC were determined using standard methods as described earlier (Table 2).

\section{Treatments}

It has been recognized that a high-yielding tea lands should have soil organic matter above $2.0 \%$ (Han et al. 2002). Generally, the well-managed tea plantations in Red Yellow Podzolic soil should have 5\% soil 
organic matter (Sandanam and Coomaraswamy 1982). The organic matter content of the present experimental soil was measured as $2.25 \%$ (organic carbon content 1.3\%). The organic matter content of the NRTWC was measured as $85.8 \%$.

Table 2: Some important physic-chemical properties of Natural Rubber Tire Waste Charcoal.

\begin{tabular}{ll}
\hline NRTWC Properties & Value \\
\hline Organic Matter (\%) & $85.87 \pm 7.15$ \\
Organic Carbon (\%) & $49.92 \pm 0.1$ \\
Bulk Density $\left(\mathrm{g} \mathrm{cm}^{-3}\right)$ & $0.2 \pm 0.005$ \\
Particle Density $\left(\mathrm{g} \mathrm{cm}^{-3}\right)$ & $0.52 \pm 0.04$ \\
Porosity (\%) & $61.53 \pm 1.33$ \\
$\mathrm{pH}$ & $7.76 \pm 1.41$ \\
$\mathrm{EC}\left(\mathrm{dS} \mathrm{m}{ }^{-1}\right)$ & $0.89 \pm 0.1$ \\
$\mathrm{NO}_{3}-\mathrm{N}^{-}\left(\mathrm{mg} \mathrm{kg}^{-1}\right)$ & $1.5 \pm 0.3$ \\
$\mathrm{NH}_{4}{ }^{+}-\mathrm{N}\left(\mathrm{mg} \mathrm{kg}^{-1}\right)$ & $23.98 \pm 0.6$ \\
Available P $\left(\mathrm{mg} \mathrm{kg}^{-1}\right)$ & $4.96 \pm 0.05$ \\
Exchangeable Ca $\left(\mathrm{mg} \mathrm{kg}^{-1}\right)$ & $416.29 \pm 57.22$ \\
Exchangeable K $\left(\mathrm{mg} \mathrm{kg}^{-1}\right)$ & $358.16 \pm 7.04$ \\
Exchangeable Na $\left(\mathrm{mg} \mathrm{kg}^{-1}\right)$ & $82.52 \pm 3.44$
\end{tabular}

Values given here are the means $(n=4) \pm$ standard deviation.

Therefore, treatment calculations were done assuming that the addition of NRTWC which contains 50\% organic carbon could increase the organic carbon content of the experimental soil up to 2.9\%. Accordingly, there were five NRTWC application rates as $1 \%$ (20\% less than requirement), $1.6 \%$ (requirement), $2.2 \%$ (20\% higher than requirement), $2.8 \%$ (40\% higher than requirement) and a control (without NRTWC application).

\section{Application of NRTWC}

Incorporation of NRTWC was done with a hand shovel. The top $10-15 \mathrm{~cm}$ of soil in the manure circle of each tea plant was selected for NRTWC incorporation. The experimental area was 0.01 ha which contained 20 individual plots each having $1.5 \mathrm{~m}$ X $1.5 \mathrm{~m}$ size. A complete randomized block design was used with four replicates. NRTWC treated and untreated plots were separated with a 1.5 $\mathrm{m}$ buffer. Each experimental plot was consisted of 8 to 10 tea bushes.

\section{Soil Sampling and Preparation for Analysis}

After 10 and 20 weeks of treatment, surface litter of the soil was removed and representative soil samples were taken from 0-15 cm depth. Composite samples were made by mixing the samples. Separate undisturbed soil samples were collected using a cylindrical core $(100$ 
$\mathrm{cm}^{3}$ ) to determine soil bulk density. Then, the plastic bags containing soil samples were sealed and transported to the laboratory. Soils were air-dried at room temperature for a week and crushed with a rubber tipped pestle. They were sieved using a $2 \mathrm{~mm}$ mesh before being analyzed.

\section{Soil Analyses}

All the analyses were done at the Soil Science laboratory of the Faculty of Agriculture, University of Ruhuna, Sri Lanka. Bulk density, particle density, porosity, soil texture and aggregate of soil samples were determined as physical properties. Soil samples taken for the determination of bulk density were ovendried at $105^{\circ} \mathrm{C}$ to a constant dry weight. Pycnometer method (Heiskanen 1992) was employed to determine particle density and soil porosity was calculated based on soil densities. Bouyoucos hydrometer method (Gee and Or 2002) was employed to measure particle-size distribution (soil texture).

Dry sieving method (Elliott 1986) was used to determine the distribution and stability of soil aggregates (oscillatory sieving analyzer, JH-200, Beijing, China). In order to isolate six aggregate size fractions, soil sample (500 g) was passed through a series of five sieves $(3,2,1.4,1$ and $0.5 \mathrm{~mm}$ ). Then, they were shaken at $280 \mathrm{rpm}$ gently for 05 minutes and impurities such as stones and roots etc., were eliminated. Finally, the weights of the mass of different particle sizes were taken and the mean weight diameter (MWD) was calculated using following equation:

$$
M W D=\sum_{i=1}^{n} \overline{X \imath} W i
$$

Where, $\bar{X} \iota$ represents the mean diameter of each size fraction $(\mathrm{mm})$ and $\mathrm{W}_{\mathrm{i}}$ stands for the proportion of the total sample mass of relevant size fraction.

\section{Statistical Analysis}

Data generated were subjected to analysis of variance (ANOVA) using SAS software (SAS Institute 1988). Duncan's New Multiple Range Test (DNMRT) was applied to test the significance of treatment means 107 Sri Lankan Journal of Agriculture and Ecosystems, 2(2):103121,2020 at $\mathrm{p} \leq 0.05$. Values were given as means $\pm \mathrm{SD}$ for triplicate samples. 


\section{Results}

\section{Bulk Density}

Figure 1 shows the changes of bulk density at 10 and 20 weeks after application of NRTWC. Low bulk density values could be observed with the increasing rate of NRTWC applications. Soils treated with NRTWC exhibited significantly $(P \leq 0.05)$ lower bulk densities for the application rates of $2.2 \%$ and $2.8 \% \quad\left(1.21\right.$ and $1.17 \quad \mathrm{~g} \mathrm{~cm}^{-3}$ respectively) than the control (0\%) where it recorded the highest bulk density value (1.39 $\left.\mathrm{g} \mathrm{cm}^{-3}\right)$ at the 10 weeks after treatment. Significantly $(P \leq 0.05)$ lower bulk densities were observed from all the NRTWC amended soils compared to control as time progressed (20 weeks after treatment). The lowest bulk density values $\left(1.17 \mathrm{~g} \mathrm{~cm}^{-3}\right.$ and $1.09 \mathrm{~g} \mathrm{~cm}^{-3}$ respectively at 10 and 20 weeks after the application of NRTWC) were recorded at the rate of $2.8 \%$ followed by at the rate of $2.2 \% \quad 1.21 \mathrm{~g} \mathrm{~cm}^{-3}$ and $1.12 \mathrm{~g} \mathrm{~cm}^{-3}$ respectively at 10 and 20 weeks after the application of NRTWC). Bulk density values were found to be not significantly $(P \geq 0.05)$ different between the application rates of $1 \%$ and $1.6 \%$ either 10 weeks or 20 weeks after application of
NRTWC. Furthermore, there were no significant $(P \geq 0.05)$ differences among the application rates of $2.2 \%$ and $2.8 \%$ either 10 weeks or 20 weeks after application of NRTWC.

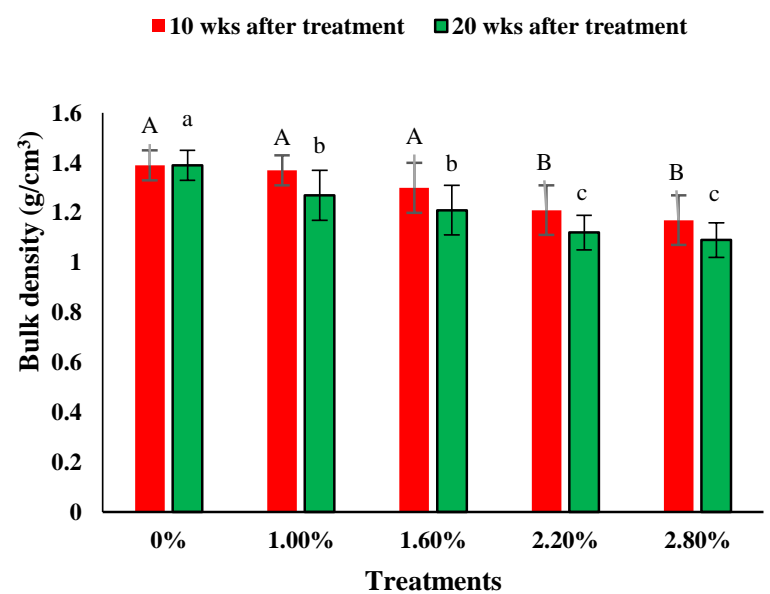

Figure 1: Changes in bulk density at 10 and 20 weeks after application of NRTWC.

Mean values indicated by same letters are not significantly different within the treatment. Values are the means $(n=4) \pm$ standard deviation.

\section{Particle Density}

Dynamics of particle density at 10 and 20 weeks after application of NRTWC are shown in Figure 2.

Low particle density values could be observed with the increasing rate of NRTWC applications. Particle density values of different treatments were not significantly $(P \geq 0.05)$ different at 10 weeks after application of NRTWC. 


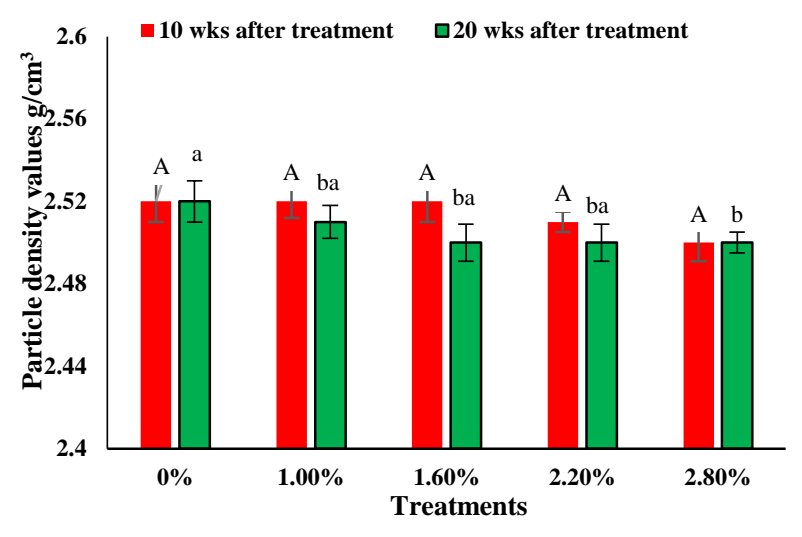

Figure 2: Changes in particle density at 10 and 20 weeks after application of NRTWC.

Mean values indicated by same letters are not significantly different within the treatment. Values are the means $(n=4) \pm$ standard deviation.

However, application rate of 2.8\% (2.52 g $\left.\mathrm{cm}^{-3}\right)$ was found to display a significant $(P$ $\leq 0.05$ ) difference compared to the control (0\%) where it recorded the highest particle density value $\left(2.49 \mathrm{~g} \mathrm{~cm}^{-3}\right)$ at the 20 weeks after treatment.

\section{Porosity}

Though no significant $(P \geq 0.05)$ variations in calculated soil porosity were observed at 10 weeks after application of NRTWC (Figure 3), the lowest porosity (44.8\%) recorded from the control at 20 weeks after application was found to be significantly $(P \leq 0.05)$ different from other treatments. No significant $(P \geq 0.05)$ variations in porosity were recorded among the application rates of either 1\% and $1.6 \%$ (49\% and 51\% respectively) and $2.2 \%$ and $2.8 \% \quad(55 \%$ and $56 \%$ respectively) at 20 weeks after application of NRTWC.

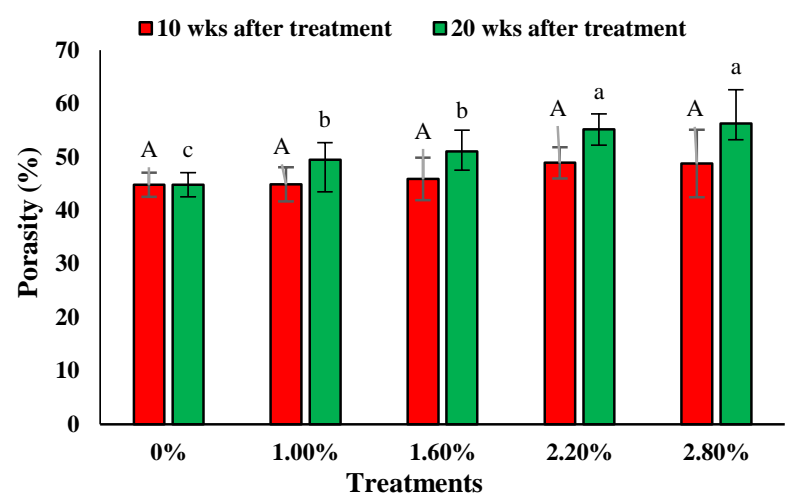

Figure 3: Changes in soil porosity at 10 and 20 weeks after application of NRTWC.

Mean values indicated by same letters are not significantly different within the treatment. Values are the means $(n=4) \pm$ standard deviation.

\section{Aggregate Stability}

Aggregate stability is commonly expressed using mean weight diameter (MWD) and it determines the size distribution of aggregates obtained by mechanical sieving (Mohanty et al., 2012). Changes of MWD at 10 and 20 weeks after application of NRTWC were shown in Figure 4. A significant increased $(P \leq 0.05)$ in soil aggregate stability was observed after application of NRTWC at 10 and 20 weeks after application compared to the control. However, soil aggregate stability of different NRTWC treatments was not significantly $(P \geq 0.05)$ varied at 10 weeks 
after application. The highest MWD (2.05) was recorded for the application rate of $2.8 \%$ after 20 weeks of NRTWC application.

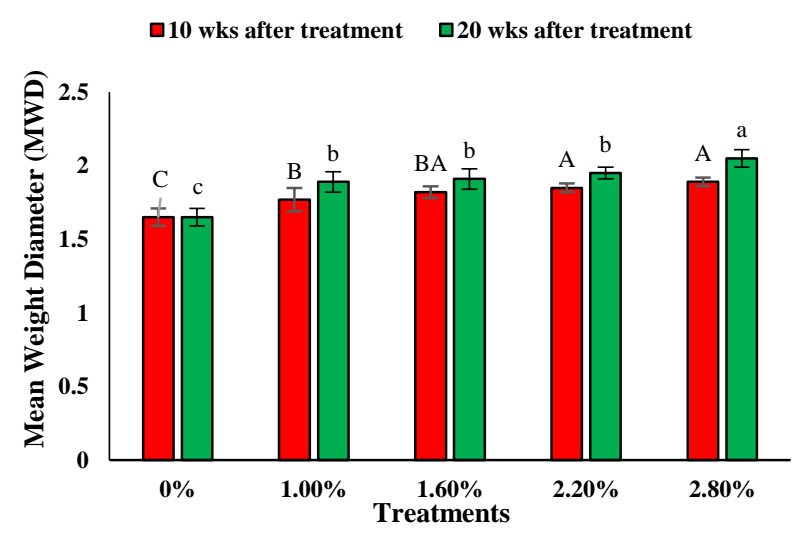

Figure 4: Changes in Mean Weight Diameter (MWD) at 10 and 20 weeks after application of NRTWC.

Mean values indicated by same letters are not significantly different within the treatment. Values are the means $(n=4) \pm$ standard deviation.

\section{Soil Texture}

No significant $(P \geq 0.05)$ variations in particle size distribution of the soil treated with NRTWC were observed at 10 and 20 weeks after application (Table 3). However, as the time progressed, there was a noticeable decreased in sand percentage while increasing silt or clay percentages (Figure 1). The highest clay content (16.9\%) was recorded at the $1.6 \%$ application rate followed by $2.2 \%$ (16.8\%) application rate at 20 weeks after NRTWC application. However, the soil texture remained unchanged (sandy loam) even 20 weeks after application of NRTWC.

Table 3: Changes in particle size distribution of soil 10 weeks after application of NRTWC.

\begin{tabular}{lllll}
\hline $\begin{array}{c}\text { Treatm } \\
\text { ents }\end{array}$ & $\begin{array}{c}\text { Sand } \\
\text { \% }\end{array}$ & Silt \% & Clay \% & $\begin{array}{c}\text { Soil } \\
\text { texture }\end{array}$ \\
\hline $0 \%$ & $73.6^{\mathrm{a}} \pm$ & $14.5^{\mathrm{b} \pm} \pm$ & $11.9^{\mathrm{b} \pm}$ & Sandy \\
& 1.8 & 2 & 0.2 & loam \\
$1.0 \%$ & $71.6^{\mathrm{a}} \pm$ & $12.7^{\mathrm{b} \pm}$ & $15.7^{\mathrm{ba} \pm}$ & Sandy \\
& 1.8 & 2 & $0.2^{\mathrm{ba}}$ & loam \\
$1.6 \%$ & $65.9^{\mathrm{b}} \pm$ & $17.2^{\mathrm{a} \pm}$ & $16.9^{\mathrm{ba} \pm}$ & Sandy \\
& 3.9 & 2.4 & 0.2 & loam \\
$2.2 \%$ & $68.5^{\mathrm{ba} \pm}$ & $14.7^{\mathrm{ba} \pm}$ & $16.8^{\mathrm{a} \pm}$ & Sandy \\
& 6.8 & 3.5 & 2.7 & loam \\
$2.8 \%$ & $71.8^{\mathrm{b} \pm}$ & $13.0^{\mathrm{b} \pm}$ & $15.2^{\mathrm{ba} \pm}$ & Sandy \\
& 4.2 & 2.7 & 2.1 & loam \\
\hline
\end{tabular}

Values are the means $(n=4) \pm$ standard deviation. Means with the same letters are not significantly different at the $5 \%$ level

Table 4: Changes in particle size distribution of soil 20 weeks after application of NRTWC.

\begin{tabular}{|c|c|c|c|c|}
\hline $\begin{array}{c}\text { Treatm } \\
\text { ents }\end{array}$ & $\begin{array}{c}\text { Sand } \\
\%\end{array}$ & Silt \% & Clay \% & $\begin{array}{c}\text { Soil } \\
\text { texture }\end{array}$ \\
\hline \multirow[t]{2}{*}{$0 \%$} & $73.6^{\text {ba }}$ & $14.5^{\mathrm{b}} \pm$ & $11.9 \mathrm{ba}$ & Sandy \\
\hline & \pm 1.8 & 2.1 & \pm 0.2 & loam \\
\hline \multirow[t]{2}{*}{$1.0 \%$} & $73.0^{\mathrm{ba}}$ & $13.8^{\mathrm{b}} \pm$ & $13.2^{\mathrm{a} \pm}$ & Sandy \\
\hline & \pm 1.8 & 2.1 & 0.2 & loam \\
\hline \multirow[t]{2}{*}{$1.6 \%$} & $74.5^{\mathrm{a} \pm}$ & $14.8^{\mathrm{b}} \pm$ & $10.7 \mathrm{ba}$ & Sandy \\
\hline & 3.9 & 2.4 & \pm 0.2 & loam \\
\hline \multirow[t]{2}{*}{$2.2 \%$} & $69.8^{\mathrm{b} \pm}$ & $21.5^{\mathrm{a} \pm}$ & $8.7^{b}$ & Sandy \\
\hline & 6.8 & 3.5 & \pm 2.7 & loam \\
\hline \multirow[t]{2}{*}{$2.8 \%$} & 71.4ba & $15.7^{b} \pm$ & $12.9 \mathrm{a} \pm$ & Sandy \\
\hline & \pm 4.2 & 2.7 & 2.1 & loam \\
\hline
\end{tabular}

Values are the means $(n=4) \pm$ standard deviation. Means with the same letters are not significantly different at the $5 \%$ level

\section{Discussion}

Soils with good physical properties provide with conducive environment for 
the enhanced movement and retention of water and nutrients thereby higher crop yields (Tokova et al. 2020). Therefore, soil physical properties are considered to the best long term soil quality indicators (Atkinson et al. 2010) and they directly or indirectly affect all biological properties and many of the chemical properties in soil (Kuht and Reintam 2004).

Optimum soil bulk density benefits nutrient transformation and the growth of plants. Higher bulk density value is the primary indicator of a compacted soil. Compacted soil will significantly reduce infiltration rate and root growth. Tea soils are relatively compacted over the years due to use of machines and human traffic through weed management and agricultural practices such as continuous trampling by pluckers. The suitable bulk density for high yielding and good quality tea cultivated soil is $1.0-1.2 \mathrm{~g} \mathrm{~cm}^{-3}$ at the surface soil and $1.2-1.45 \mathrm{~g} \mathrm{~cm}^{-3}$ at the sub surface soil (Ping et al. 2014).

Organic matter content is a decisive factor of bulk density (Ruehlmann and Körschens 2007) thus there is a strong correlation between them (Nascente et al. 2015). Organic matter content determines the weight of the soil influencing bulk density (Pravin et al. 2013). The increase in bulk density in tea cultivated lands is attributed to the reduction of organic matter due to excessive erosion, longterm cultivation in the same land and negligence in the application of organic manure over a long period of time. Most of the tea soils are below the critical carbon level in Sri Lanka (Illukpitiya et al. 2004). Bulk density values range from $1.39 \mathrm{~g} \mathrm{~cm}^{-3}$ (control soil) to 1.17 and 1.09 $\mathrm{g} \mathrm{cm}^{-3}$ (at 2.8\% NRTWC application) respectively for 10 and 20 weeks after NRTWC application. Soil organic matter content is found to be increased significantly $(P \leq 0.05)$ with increasing rates of NRTWC application.

The highest organic carbon $(3.2 \%)$ is recorded with the $2.8 \%$ NRTWC application followed by $2.2 \%$ application $(2.7 \%)$ at the 20 weeks after the treatment (unpublished data). The porosity (61\%) and organic matter content (85.8\%) of charcoal are comparatively high. Thus application of NRTWC could result in lowered bulk density values of soil. Thus, application of NRTWC resulted in significantly decreased bulk density through increased pore volume and decreased weight of the 
soil. Tsuchiya (1991) also found that the addition of rubber crumb, natural rubber, and other elastic organic polymers to soil as soil amendments improve soil quality and prevent soil compaction.

The particle density is considered to be one of the basic physical properties of soil. It depends on the composition of both the mineral and the organic soil components (Ruehlmann and Körschens 2007) and varies considerably across soil types and geographical regions (Rühlmann et al. 2006). Particle density is an important attribute of a soil though it is not often measured.

Generally, particle density of a soil is considered to be a constant $\left(2.65 \mathrm{~g} \mathrm{~cm}^{-3}\right)$ when soil porosity calculations are made. However, variations in organic matter content in soil may cause significant reductions in soil particle density (BlancoCanqui et al. 2006). The particle density of organic materials is often varied with a range of 1.5 to $2 \mathrm{~g} \mathrm{~cm}^{-3}$ (Brewer et al. 2009), while particle density of a mineral soil could vary from 2.4 to $2.8 \mathrm{~g} \mathrm{~cm}^{-3}$. There is a strong negative correlation between organic matter content and particle density of a soil (Schjønning et al.
2017). Therefore, the decreased trend of soil particle density with the addition of NRTWC is attributed to the high organic matter content and low particle density of charcoal particles.

Soil porosity is an important property because it affects infiltration, root penetration, available water capacity, plant nutrient availability, and soil microorganism activity, which are very important in soil processes and productivity. As stated by Blanco-Canqui (2017), addition of organic materials could enhance soil porosity through lowering soil bulk density and increasing soil aggregation. The porosity of organic amendments often varies from 70 to $90 \%$ thus, addition of them could increase soil porosity. Yilmaz and Degirmenci (2009) observed that incorporation of waste tire rubber along with fly ash could reduce the soil compaction and increase porosity to a great extent.

According to previous studies, addition of charcoal to agricultural soils increases water holding capacity and decreases nutrient leaching due to porous nature with high water- and air retention capacities of charcoal (Laird et al. 2010). 
When the two-testing periods were compared (Figure 3), the porosity values increased with time. It might be due to the increment of soil organic matter content with the application of treatments. After the addition of NRTWC, the highest porosity change was observed at 1\% treatment (from $44.9 \%$ to $48.8 \%$ ) and the lowest was at $2.8 \%$ (from $49.4 \%$ to $56.3 \%$ ). Present results are in agreement with William and Shenker (2016) who reported increased porosity and decreased bulk density after adding the pulverized tires to the soil. Zhao et al. (2011) also observed that crumb rubbers improved the properties of amended sand-based medium by decreasing bulk density and improving water retention. Crumb rubber contains some plant micronutrients and degrades similar to other organic amendments.

The suitable soil texture for the cultivation of tea is loam sand to sandy loam (Jayasinghe et al. 2019). Though particle size distribution slightly changed after application of NRTWC, the soil texture remained unchanged as sandy loam. In the present study, a reduction in larger particle size (sand particles) and increment in smaller particle size (silt and clay particles) were observed.

Soil aggregates are principally formed by adhering soil colloidal particles together due to net attractive forces among them. Soil aggregate stability highly correlates with clay, organic matter and calcium carbonate content of the soil. Addition of organic material could enhance soil aggregation and soil aggregate stability which ultimately result in good soil structure. Many researchers have observed interrelation between organic matter content and soil aggregation (Tisdall and Oades 1982; Six et al. 2000). In the present study, the control soil recorded the lowest MWD which might be due to poor organic matter content of soil. Bosco and Molleae (2021) found that naturally available soil microorganisms were able to use natural rubber as the only carbon source through the biodegradation and eventually increase soil carbon content.

\section{Conclusions}

According to the present findings, the addition of NRTWC had a significant impact on major physical characteristics of tea growing soil. The application of 
NRTWC significantly reduced the bulk density, thereby increased porosity and aggregate stability. Therefore, use of NRTWC as a soil amendment at the rate of $2.8 \%$ could be considered as one of the possible alternative management practices for maintaining favorable soil physical conditions, particularly in tea soils with low organic matter content. However, more studies are needed to explore the long term impact of NRTWC incorporation at various rates and various growth stages of tea plants under field conditions. Furthermore, enhancement of soil chemical and biological properties with the addition of NRTWC should be investigated.

Conflicts of Interest: The authors have no conflicts of interest regarding this publication.

\section{References}

Al-Neami, M A 2018 Stabilization of sandy soil using recycle waste tire chips. Int J Geomate 15:175-180. DOI: 10.21660/ 20 18.48 .180228 .

Atkinson C J, Fitzgerald J D \& Hipps N A 2010 'Potential mechanisms for achieving agricultural benefits from biochar application to temperate soils: A review', Plant Soil 337: 1-18. DOI:10.1007/s11 104-010-0464-5.

Blackmore L C, Searle P L \& Daly B K 1987, 'Methods of Chemical Analysis of Soils', NZ Soil Bureau, Scientific Report 80.

Blanco-Canqui, H, Lal R, Izaurralde, R C, Post, W M \& Shipitalo, M J 2006, 'Organic carbon influences on particle density and rheological properties for a silt loam soil' Soil Sci Soc Am J 70: 1407-1414. DOI:10.2136/sssaj2005.0355.

Bosco, F \& Mollea, C 2021, 'Biodegradation of Natural Rubber: Microcosm Study', Water Air Soil Pollut 232: $227 . \quad$ DOI:10.1007/s11270-02105171-7.

Bremner, J M \& Mulvaney, C S 1982, 'Total nitrogen. In. A.L.Page (eds.) Methods of Soil Analysis. Part 2. Chemical and Microbiological Methods', 2nd Edition. Amer. Soc. Agron. pp. 1149-1178.

Brewer, C E, Schmidt-Roh,r K, Satrio, J A \& Brown, R C 2009, 'Characterization of biochar from fast pyrolysis and gasification systems', Environ Prog 
Sustain Energy 28:386-396.

DOI:10.1002/ep.10378.

Central Bank Report , 2020, https:// www.cbsl.gov.lk/en/publications/econo mic-and-financial-reports/annualreports/annual-report-2020.

Chaudhari, P R, Ahire, D V, Ahire, V D, Chkravarty, M \& Maity, S 2013, 'Soil bulk density as related to soil texture, organic matter content and available total nutrients of Coimbatore soil', Int J Sci Res Pub 3: 1-7. 59.

Czajczynska, D, Krzyzynska, R, Jouhara, H \& Spencer, N 2017, 'Use of pyrolytic gas from waste tire as a fuel: A review', Energy 134: 1121-1131. DOI:10.1016/j.e nergy.2017.05.042.

Dhir, R K, Limbachiya, M C \& Paine, K A 2001, 'Recycling and reuse of used tires', London: Thomas Telford Publishing. DOI:10.1016/j.apsoil.2011.06.011.

Duan, P, Jin, B, Xu, Y \& Wang, F 2015, 'Copyrolysis of microalgae and waste rubber tire in supercritical ethanol', Chem Eng J 269: 262-271. DOI:10.1016/j.cej.2015 .01 .108 .
Elliott, E T 1986, 'Aggregate structure and carbon, nitrogen, and phosphorus in native and cultivated soils', Soil Sci Soc Am J 50: 627-633. DOI:10.2136/sssaj1 986.03615995005000030017x.

Gee, G W \& Or, D 2002, 'Particle Size Analysis. In: Dane, J. H., \& Topp, G. C., Eds., Methods of Soil Analysis, Part 4, Physical Methods', Soils Science Society of America , Book Series No. 5, Madison, 255-293.

Gunathilaka, R P D, Smart, J C \& Fleming C M 2018, 'Adaptation to climate change in perennial cropping systems: Options, barriers and policy implications', Environ Sci Policy 82: 108-116. DOI:10.1016/j. envsci.2 018.01.011.

Han, W Y 2002, 'The major nutrient limiting factors in tea soils and development of series tea speciality fertilizers', Sri Lanka J Tea Sci 22: 70-74.

Heiskanen, J 1992, 'Comparison of three methods for determining the particle density of soil with liquid pycnometers', Commun Soil Sci Plant Anal 23: 841-846. DOI:10.1080/00103629209368633.

Illukpitiya, P, Shanmugaratnam, N \& Kjosavik, D J 2004, 'Tea agro-ecosystems in the Uva Highlands of Sri Lanka-An 
evaluation of land management activities', Mt Res Dev 24: 52-59. DOI:10.1659 /0276-4741(2004)024 [005 2 : TAI TUH]2.0.CO;2.

Jayasinghe, S L, Kumar, L \& Sandamali, J 2019, 'Assessment of potential land suitability for tea (Camellia sinensis (L.) 0. Kuntze) in Sri Lanka using a GIS-based multi-criteria approach', Agriculture 9: 148. DOI:10.3390/agriculture9070148.

Juma, M, Koreňová, Z, Markoš, J, Annus, J \& Jelemenský, L' 2006, 'Pyrolysis and combustion of scrap tire', Pet Coal 48: 15 -26 .

Junqing, $\mathrm{X}$, Jiaxue, $\mathrm{Y}$, Jianglin, $\mathrm{X}$, Chenliang, $S$, Wenzhi, H, Juwen, $H$ \& Guangming, L 2020, 'High-value utilization of waste tires: A review with focus on modified carbon black from pyrolysis' Sci Total Environ 742. DOI: 10.1016/j.scitot env. 2020.140235 .

Kuht, J \& Reintam, E 2004, 'Soil compaction effect on soil physical properties and the content of nutrients in spring barley (Hordeum vulgare L.) and spring wheat (Triticum aestivum L.)', Agron Res 2:187-194.
Laird, D A, Fleming, P, Davis, D D, Horton, R, Wang, B \& Karlen, D L 2010, 'Impact of biochar amendments on the quality of a typical midwestern agricultural soil', Geoderma 158, 443-449. DOI:10.1016/j. geoderma.2010.05.013.

Lal, R 2015, 'Restoring soil quality to mitigate soil degradation', Sustainability 7: 5875-5895.

Li, S, Wan, C, Wu, X \& Wang, S 2016, 'Coreshell structured carbon nanoparticles derived from light pyrolysis of waste tires' Polym Degrad Stab 129: 192-198. DOI:10. 1016/j.polymdegradstab.2016.04.013.

Mapa, R B, Kumaragamage, D, Gunarathne, W D L \& Dassanayake, A R 2002, 'Land use in Sri Lanka: Past, present and the future', In: Proceedings of the 17th World Congress of Social Science (WCSS), Bangkok, Thailand.

Mapa, R B, Somssiri, S \& Nagarajah S 1999, 'Soils of the wet zone of Sri Lanka. Soil Sci Soc Sri Lanka', Sri Lanka. pp 2392.

Murphy, J \& Riley, J P 1962, 'A modified single solution method for the determination of phosphate in natural waters', Analytica Chimica Acta, 27: 31- 
36. DOI: $10.1016 /$ S0003- 2670(00)88 444-5.

Nascente, A S, Stone, L F \& Crusciol, C A C 2015, 'Soil chemical properties affected by cover crops under no-tillage system', Soil Sci Plant Nutr 62: 401-409. DOI:10.1590/0034737X201562040010.

Nehdi, M \& Khan, A 2001, 'Cementitious composites containing recycled tire rubber: an overview of engineering properties and potential applications', Cem Concr aggre 23: 3 -10. DOI:10.15 20/CCA10519J.

Ping, X, Liyun, Y, Moucheng, L \& Fei, P 2014, 'Soil Characteristics and Nutrients in Different Tea Garden Types in Fujian Province, China', J Resour Ecol 5: 356-363, DOI:10.5814/j.issn.1674-

764x.2014.04.011.

Rühlmann, J \& Körschens, M 2007, 'Calculating the Effect of Soil Organic Matter Concentration on Soil Bulk Density', Soil Sci Soc Am J 73: 876-885 DOI:10.2136/sssaj2007.0149.

Rühlmann, J, Körschens, M \& Graefe, J 2006, 'A new approach to calculate the particle density of soils considering properties of the soil organic matter and the mineral matrix', Geoderma 130: 272283. DOI:10.1016/j.geoderma.2005.01.0 24

Sandanam, S \& Coomaraswamy, A 1982), 'Effects of soil management on some physical properties of a Red Yellow Podzolic tea soil', Tea Quart 51: 75-85.

SAS Institute 2000, SAS/STAT user's guide. SAS Institute Inc. Cary, NC.

Schjønning, P, McBride, R A, Keller, T \& Obour P, B 2017, 'Predicting soil particle density from clay and soil organic matter contents', Geoderma 292: 83-87. DOI:10.1 016/j.geoderma.2016.10.020.

Searle, P L 1984, 'The Berthelot or indophenol reaction and its use in the analytical chemistry of nitrogen: a review', Analyst 109: 549-568.

Six, J, Elliott, E T \& Paustian K 2000, 'Soil macroaggregate turnover and microaggregate formation: A mechanism for $\mathrm{C}$ sequestration under no-tillage agriculture', Soil Biol Biochem 32: 20992103. DOI:10.1016/S0038-0717(00)0 01 $79-6$.

Thomas, B S, Gupta, R C \& Panicker, V J 2016, 'Recycling of waste tire rubber as 
aggregate in concrete: durability -related performance', Clean Prod 112: 504 -513. DOI10.1016/j.jclepro.2015.08.046.

Tisdal, J M \& Oades, J M 1982, 'Organic matter and water-stable aggregates in soils', J Soil Sci 33: 141-163. DOI:10.11 11/j.1365-2389.1982.tb01 755.x.

Tiessen, H \& Moir, J $O$ 1993, 'Total and organic carbon. In: M R Carter (eds.), Soil Sampling and Methods of Analysis', Cana. Soc. Soil Sci. Lewis Publishers, Boca Raton, Fl. USA. 187-199.

Toková, L, Igaz, D, Horák, J \& Aydin, E 2020, 'Effect of biochar application and re-application on soil bulk density, porosity, saturated hydraulic conducti vity, water cntent and soil water availability in a silty loam Haplic Luvisol', Agronomy 10: 1005. DOI:10.3390/ agronomy10071005.

Tsuchiya, G K K 1991, 'Improved soil composition used as soil conditioner - is obtained by \&hg elastic organic polymer with gravel, sand clay etc', Japanese Patent 3,017,184.

Undri, A, Meini, S, Rosi, L, Frediani, M \& Frediani, P 2013, 'Microwave pyrolysis of polymeric materials: Waste tires treatment and characterization of the value-added products', J Anal Appl Pyrol
103: 149-158. DOI:10.1016/j.jaap.201 2.11.011.

Wang, F, Hong, R Y, Feng, W G, Badami, D \& Zeng K 2014, 'Electrical and mechanical properties of ABS/EPDM composites filled with carbon black', Mater Lett 125: 48-50. DOI:10.1016/j.matlet.2014.03.136.

William, M \& Shenker, M 2016, 'Pulverized tires as soil amendment for plant growth', Int J Sci Eng Res 7:161-167.

Williams, P T 2013, 'Pyrolysis of waste tyres: a review', Waste Manag 1714e1728.

Yilmaz, A \& Degirmenci, N 2009, 'Possibility of using waste tire rubber and fly ash with Portland cement as construction materials', Waste Manag 29: 1541-1546. DOI:10.1016/j.wasman. 200 8.11.002.

Zhang, X, Li, H, Cao, Q, Jin L \& Wang, F 2018, 'Upgrading pyrolytic residue from waste tires to commercial carbon black', Waste Manag Res 36: 436-444. DOI:10 $.1177 / 0734242 \times 18764292$.

Zhao, S, He, T \& Duo, L 2011, 'Effects of crumb rubber waste as a soil conditioner on the nematode assemblage in a turfgrass soil', Appl Soil Ecol 49: 94-98. DOI:10.1016/j.apsoil.2011.06.011. 